\title{
The Concept and Historical Background of Custody Evaluation
}

\author{
Myung Hoon Lee', Dong Sun Chung'2, Duk Soo Moon ${ }^{3}$, and Young Sook Kwack ${ }^{3}$ \\ ${ }^{1}$ Raon Psychiatric Clinic, Incheon, Korea \\ ${ }^{2}$ W Psychiatric Clinic, Seongnam, Korea \\ ${ }^{3}$ Department of Psychiatry, Jeju National University School of Medicine, Jeju, Korea
}

\begin{abstract}
This article reviews a wide range of literature on the standards and process of child custody evaluation in the US, and proposes custody evaluation standards appropriate to Korea. Custody evaluation refers to the process of making psychiatric and psychological evaluations of each parent and the child during a custody dispute and presenting to the family court a report of custody evaluation with the aim of safeguarding the best interests of the child. In the past, it was thought that children arethe fathers' possessions or that younger children should be raised by the mother; however, currently, custody rights are evaluated in accordance with the principle of the best interests of the child. The principle is all-encompassing and vague and hence, the court makes increasingly more requests to mental health professionals for custody evaluation. Since the Seoul Family Court introduced the expert consultation system in 2017, the involvement of mental health professionals in child custody decisions has increased in Korea. Custody evaluators should try to be neutral and find the objective facts, keeping in mind that their role is to aid the court in making a custody decision.
\end{abstract}

Key Words: Child custody; Divorce; Best interest; Family court; Forensic psychiatry.

Received: February 17, 2020 / Revised: February 24, 2020 / Accepted: February 26, 2020

Address for correspondence: Dong Sun Chung, W Psychiatric Clinic, 178 Pangyoyeok-ro, Bundang-gu, Seongnam 13524, Korea

Tel: +82-31-8016-6663, Fax: +82-31-8016-6664, E-mail: dschungh@gmail.com

\section{INTRODUCTION}

The family court may consult mental health professionals for child custody evaluation if the parents are in a bitter custody dispute or if each parent's pros and cons are not clear such that it is difficult to determine which parent's custody would be in the best interests of the child. However, some mental health professionals may experience confusion when consulted for custody evaluation because they are unfamiliar with evaluation standards or the process. Accordingly, this article was written to suggest standards of child custody evaluation pertinent to Korea, based on a review of a wide range of literature on the US standards and the process of child custody evaluation. To conduct a review, relevant literature was searched by entering the following terms in the PubMed search engine: child custody evaluation, forensic psychiatry, custody evaluation standard, divorce, and psychological tests in custody evaluation. Of the search results of articles and books that suggested custody evaluation standards or approaches, those that were considered meaningful by the researchers were further examined.

This is an Open Access article distributed under the terms of the Creative Commons Attribution Non-Commercial License (https://creativecommons.org/licenses/by-nc/4.0) which permits unrestricted non-commercial use, distribution, and reproduction in any medium, provided the original work is properly cited.

\section{MAIN ISSUES}

\section{Definition of custody evaluation}

Custody evaluation refers to the formation of an opinion on either party's right to custody and reporting to the family court, the petitioner, the respondent, and the lawyers of either party when there is a custody dispute between the mother and the father (or other primary caregivers). Custody evaluation may be ordered by the court or requested by one of the parents $[1,2]$. Custody can generally be classified into two categories [3].

Legal custody refers to a parent's right to make important decisions regarding the child. The parent with sole custody has the right to make important decisions regarding the child's everyday life and specifically, education, healthcare, and religion. In the case of joint custody, both parents share the right to make important decisions, whereas everyday decisions can be made autonomously by the parent living with the child at the time the decisions are being made.

Physical custody refers to a parent's right regarding how much time to spend with the child. When custody is given to one parent, the child spends most of the time with that parent and the other parent usually only has "visitation rights" according to a certain agreement (e.g., during the evening of a 
weekday or every other weekend). Under joint custody, the child spends an equal amount of time with each parent. In the US, sleeping with the child in the same living quarter for an average of 2 nights per week is defined as the minimum for joint custody. This definition is in line with the Child Protection Act in the US, according to which a condition of joint custody is having the child approximately 100 nights in a year [4].

The American Psychological Association (APA), Association of Family and Conciliation Courts (AFCC), and American Academy of Child and Adolescent Psychiatry (AACAP) each have developed guidelines for custody evaluation $[1,2,5]$. All of them recommend that the child's present and future needs, and each parent's ability to meet them should be evaluated. The APA and AACAP guidelines make additional recommendations for evaluating each parent with respect to their ability to raise the child and provide a stable and loving family environment, the potential for inappropriate behavior negatively impacting the child (e.g., drug abuse), and what the child wants.

\section{Purpose of custody evaluation}

The purpose of custody evaluation is to mediate a parenting environment to safeguard the best interests of the child. To do so, such elements as family dynamics and interaction, cultural and environmental factors, and the child's psychological and developmental characteristics are assessed, and their educational, physical, and psychological needs are identified [1].

The level of conflict in the couple going through a divorce is a variable critical to the future psychological state of the child and family relations. If parents are undergoing severe conflict during a divorce, parent-child relationships are likely to get worse and the child is likely to experience anxiety in relationships with others and feel that he/she has no social support system to receive help [6]. The more severe the conflict between the parents going through a divorce, the more likely the child will have emotional or behavioral problems [7]. Therefore, if custody evaluation can minimize parental conflict, it will help in keeping the child's best interests [8].

\section{Custody evaluator qualifications}

APA guidelines state that custody evaluators should be objective and fair and that professional experts with aboveaverage skills in clinical evaluation of children, adults, and families would be expected to play a role. Indeed, custody evaluators should have professional competencies not only in the knowledge of the evaluation process but also in specific knowledge in developmental psychology, family dynamics, psychopathology, and divorce and custody laws. The guidelines also caution that mental health professionals should never do more than playing a role of a fair evaluator and should refrain from expressing their opinion on issues regarding custody and visitation, unless ordered by the court. Custody evaluators should make recommendations on the basis of clear assumptions, interpretations, and inferences pertaining to professional and scientific criteria [2].

AFCC guidelines state that custody evaluators should be knowledgeable in developmental psychology, child interviewing techniques, custody evaluation process, family violence, substance abuse, child abuse, and neglect, etc., and that they should receive continued education in the relevant areas [1].

American Academy of Matrimonial Lawyers (AAML) recommends that custody evaluators should have formal education and training in legal, social, familial, and cultural issues pertaining to custody rights, and have either a master's degree in a mental health field or a Juris Doctor degree. AAML also recommends that custody evaluators should have at least three years of experience conducting custody evaluation or should have conducted at least 20 custody evaluations and that those with less experience in custody evaluation should seek ongoing supervision from an experienced custody evaluator [9].

The discussion above can be summarized as follows.

1) Custody evaluators should have up-to-date knowledge regarding child development, and child and family psychopathology.

2) Custody evaluators should be knowledgeable in legal and ethical standards relevant to custody evaluation. They should also be familiar with the legal context of decisions on child custody and custody schedule and the legal process of custody evaluation.

3) Custody evaluators should be fair. They should selfcheck their personal values and ideas, and be able to consult colleagues if they think they may have a bias.

4) Custody evaluators should be well aware of cultural differences and should avoid cultural discrimination. Specifically, they should be aware of their own biases regarding age, gender, gender identity, race, language, culture, disability, nationality, socioeconomic status, and so on.

5) Custody evaluators should avoid conflict of interest or conflict arising from a variety of relationships.

(1) If custody evaluators are already acquainted with either parent or the child involved in the evaluation due to other relationships, (2) if it is likely in the future for custody evaluators to provide therapy to either of the parents and the child involved in the evaluation, the family, and friends, or (3) if custody evaluators are requested to conduct custody evaluation involving a past or present therapy client, they may refuse the court's request for custody evaluation.

6) Custody evaluators should collect the data in regard to 
custody evaluation in earnest, interview the involved parties in the evaluation, and conduct necessary tests. Additionally, they should obtain information from collateral sources, if any, and present an effective summary of the evaluation to the court.

7) Custody evaluators should have additional professional training for special cases, such as,

- Child sexual abuse.

- Child abuse.

- Family violence.

- Parent/child psychiatric evaluation.

- Evaluation of a parent's emigration request.

- Substance abuse.

- Sexual orientation issue.

8) Custody evaluators should have training in the use of official evaluation tools. They should have sufficient training and experience in selecting and executing official evaluation tools and be proficient in interpreting test results. They should also be able to explain why a particular evaluation tool was chosen. In interpreting test results, custody evaluators should keep in mind that the results can be influenced by individual differences in test-taking ability, personality, language, and culture, and explicitly state any limitations in the evaluation process and interpretation. If using an evaluation tool not validated in forensic psychiatry, custody evaluators should describe the strengths and limitations of the test results and make inferences within the context of forensic psychiatry when presenting the results.

\section{The process of the court's request for custody evaluation}

Custody evaluators registered as court diagnostic professionals or court consultants receive requests for custody evaluation from a court child and family investigator via phone or other means. If custody evaluators verbally accept the request, the court sends them evaluation referral forms. After a review of the referral forms, custody evaluators may refuse to conduct the custody evaluation if it is deemed inappropriate to conduct the evaluation (e.g., if any of the parents and the child involved in the custody evaluation was, or currently is, a therapy client).

\section{Historical changes in the perspective of custody}

In the West, custody laws were very clear until the 19th century. The wife and children were considered the husband's possessions and thus, the father automatically had the custody right [10]. In the late 1800 s, the Tender Years Doctrine emerged, which assumed that mothers are better suited to rearing children. Changes started to occur [11-13], following the idea that naturally, mothers may raise children better. In the 20th century, custody rights were mainly determined on the basis of the Doctrine, but that line of thinking received criticism for sexual discrimination in the 1970s $[13,14]$. As the court started to take on the principle of the best interests of the child, proposed in the early 20th century, the guidelines based on the Tender Years Doctrine, which had been utilized until then, became obsolete [15]. As per the new principle, the child's needs are regarded as the most important in a custody decision. In a process of custody evaluation based on the child's best interests, the court opts for the child-rearing environment in which the child's wellbeing and development would be the least interfered, and mediates using the least harmful approach. In a custody decision based on the child's best interests, the child's need for continuing relationships should be seriously considered. In addition, custody evaluators should not make a hasty prediction as to how the child's relationships will change in the future [16].

Several factors are thought to be related to the best interests of the child. They include the child's and the parents' wishes regarding custody; the child's wish regarding who will raise him/her; the child's interactions with people around him/her, including the parents and siblings; how the child has adjusted at home, at school, and in the community; and the mental and physical health of the child and the main caregiver [17]. However, no clear and specific evidence was presented under the principle of the best interests of the child. Thus, the judges started to request mental health professionals for custody evaluation in order to identify the best interests of the child [15,18-20].

The principle of "the best interests of the child" is widely criticized because, to a large extent, custody decisions are at the judges' discretion in the absence of specific criteria. Since it is difficult to predict a judge's decision, a lawsuit is recommended and conflict escalates during the dispute as each parent presents evidence against the other to the court (parents' moral fitness is viewed as important in some cases). Additionally, the possibility of bias increases because a great deal of discretionary power is given to the judges [21]. Due to these problems, a critic of law once stated that simply tossing a coin might be better [22]. According to the "approximation rule," child custody should be determined in accordance with the amount of time each parent has spent in raising the child in the marriage [23]. Couples who have been equally engaged in child rearing will be awarded with joint physical custody, whereas those who have not, will be awarded with a child custody similar to their past pattern. The most important advantage of the approximation rule is that the criterion is clear and final. Because parents and lawyers can predict the court's decision, they will try to reach an agreement. Nevertheless, 
Table 1. Differences between clinical and forensic evaluations

\begin{tabular}{|c|c|c|}
\hline & Clinical evaluation & Forensic evaluation \\
\hline Purpose & Relieve suffering & Answer a legal question \\
\hline Relationship & Doctor-patient & Evaluator-evaluated \\
\hline Client & The patient & The court, attorney, or other retaining agency \\
\hline Objective & Help heal the patient & $\begin{array}{l}\text { By report or testimony, inform and teach the retaining agency } \\
\text { and fact finder, i.e., judge or jury }\end{array}$ \\
\hline Privacy & Confidentiality usually applies & Privilege may apply \\
\hline Process & Establish diagnosis and treatment plan & Conduct objective evaluation; diagnosis may be nonessential \\
\hline Treatment & Treatment rendered & No treatment rendered, although it may be recommended \\
\hline Sources & $\begin{array}{l}\text { Self-report; occasionally outside } \\
\text { information; some collateral records }\end{array}$ & $\begin{array}{l}\text { Extensive collection of data including serial interviews, } \\
\text { information from additional historians, review of records and } \\
\text { documents; }\end{array}$ \\
\hline Bias & $\begin{array}{l}\text { Therapeutic bias occurs; desire for patient toget } \\
\text { better; willingness to advocate for patient }\end{array}$ & $\begin{array}{l}\text { Purposeful lack of bias; attempt to be neutral and objective; } \\
\text { no investment in outcome }\end{array}$ \\
\hline End product & $\begin{array}{l}\text { Establish therapeutic relationship; } \\
\text { improve well-being of patient }\end{array}$ & $\begin{array}{l}\text { Answer the referral question in the form of a verbal or written } \\
\text { report; deposition; and/or testimony }\end{array}$ \\
\hline
\end{tabular}

Adapted from Kraus et al. J Am Acad Child Adolesc Psychiatry 201 1;50:1299-1312 [5].

in custody disputes resulting in a lawsuit, the rule places too much restriction on the scope of legal investigation and custody evaluation. Under the approximation rule, the judge and the custody evaluator will focus only on how much time each parent spent in raising the child in the past [24]. The rule is criticized because in general, fathers spend less time in child rearing but a child can form a stable attachment to the father as well as to the mother, and mothers experiencing postpartum depression may form an unstable attachment with the child in spite of spending most of their time in child rearing [25]. Some couples agree that one parent would care for the child full-time, and it is also possible to abuse the approximation rule. For example, parents who are unhappy with their marriage, who quit working to spend more time with the child, and parents who position themselves more advantageously in a custody dispute after intentionally being fired. Accordingly, it is not sensible to make custody evaluations on the basis of the approximation rule alone.

Presently, custody evaluation is made on the basis of the best interests of the child and using diverse theories and rules such as attachment theory and the approximation rule. In Korea, recently the number of cases where the court makes requests for custody evaluation to professionals in child mental health is growing, as is the idea that relevant factors in the mediation of custody rights should not be determined simply by an agreement between the parents alone, for children are not their possessions [26]. In March 2017, the Seoul Family Court introduced the expert consultation system for divorced families and child custody in family litigation and family conciliation process [27]. The procedure for consulting appointed advisory members, including psychiatrists, psychologists, and child counselors, was also put into place for child custody cases requiring further evaluation.

In the future, the likelihood of biological and social parents to dispute a child custody will increase due to the advancements in gene testing, and fertilization and impregnation techniques [28].

\section{The role of child-adolescent psychiatrists}

In forensic psychiatric evaluation, child-adolescent psychiatrists should try not to empathize with the patient's feelings or provide help. Rather, they should scrutinize whether each parent's statements are truthful and should always question whether or not the child's statements are distorted due to parental influence. Table 1 shows the differences between therapy and forensic psychiatric evaluation. It is noteworthy that statements made by the parties involved in a forensic psychiatric evaluation are not confidential.

Child-adolescent psychiatrists should evaluate the child and each parent with fairness based on enriched psychiatric knowledge and deliver a report in accordance with the aim of the best interests of the child [29]. The role of child-adolescent psychiatrists is to aid the judges in makinga custody decision; final decisions are made by the judges.

\section{CONCLUSION}

Custody evaluation refers to the process of making psychiatric and psychological evaluations of each parent and the child during a custody dispute, and presenting to the court a report of custody evaluation aimed at the best interests of the child. Custody evaluators should be well versed in psychi- 
atric and psychological knowledge, and also be familiar with relevant laws and the evaluation process. In conducting custody evaluation, they should be neutral and try to find out the objective facts. They do not make the final decision on a child's custody, but they help the judge in making a decision.

\section{Acknowledgments}

None.

\section{Conflicts of Interest}

The authors have no potential conflicts of interest to disclose.

\section{Author Contributions}

Project administration: Dong Sun Chung. Supervision: Young Sook Kwack. Writing_original draft: Myung Hoon Lee. Writing_review \& editing: Dong Sun Chung, Duk Soo Moon.

\section{ORCID iDs}

Myung Hoon Lee https://orcid.org/0000-0002-9616-7563

Dong Sun Chung https://orcid.org/0000-0001-9033-5004

Duk Soo Moon https://orcid.org/0000-0001-7878-3410

Young Sook Kwack https://orcid.org/0000-0002-6071-238X

\section{REFERENCES}

1) Task Force for Model Standards of Practice for Child Custody Evaluation, Martindale DA, Lorraine M, Austin WG, Drozd L, Gould-Saltman D, et al. Model standards of practicefor child custody evaluation. Fam Court Rev 2007;45:70-91.

2) American Psychological Association. Guidelines for child custody evaluations in family law proceedings. Am Psychol 2010;65:863-867.

3) Emery RE, Otto RK, O'Donohue WT. A critical assessment of child custody evaluations: limited science and a flawed system. Psychol Sci Public Interest 2005;6:1-29.

4) Maccoby EE, Mnookin RH. Dividing the child: Social and legal dilemmas of custody. Cambridge, MA: Harvard University Press; 1992.

5) Kraus LJ, Thomas CR, Bukstein OG, Walter HJ, Benson RS, Chrisman A, et al. Practice parameter for child and adolescent forensic evaluations. J Am Acad Child Adolesc Psychiatry 2011;50:12991312.

6) Riggio HR. Parental marital conflict and divorce, parent-child relationships, social support, and relationship anxiety in young. Pers Relationships 2004;11:99-114.

7) Johnston JR. High-conflict divorce. Future Child 1994;4:165-182.

8) Goldstein J, Freud A, Solnit A. Beyond the best interests of the child. New York, NY: Free Press;1973.

9) American Academy of Matrimonial Lawyers. Child Custody Evaluation Standards. J Am Acad Matrimonial Law 2013;25:251-294.
10) Wyer MM, Gaylord SJ, Grove ET. The legal context of child custody evaluations. In: Weithorn LA, editor. Psychology and child custody determinations: knowledge, roles, and expertise. Lincoln, NE: University of Nebraska Press;1987. p.4-22.

11) JUSTIA US Law. Ex Parte Devine [cited 2020 Jan 31]. Available from URL: https://law.justia.com/cases/alabama/supremecourt/1981/398-so-2d-686-1.html.

12) Lyman RD, Roberts MC. Mental health testimony in child custody litigation. Law Psychol Rev 1985;9:15-34.

13) Mason MA. From father's property rights to children's rights: the history of child custody in the United States. New York, NY: Columbia University Press;1994.

14) Hall AS, Pulver CA, Cooley MJ. Psychology of the best interest standard: fifty state statutes and their theoretical antecedents. Am J Fam Ther 1996;24:171-180.

15) Mnookin RH. Child-custody adjudication: Judicial functions in the face of indeterminacy. Law Contemp Probl 1975;39:226-293.

16) Goldstein J, Freud A, Solnit AJ. Before the best interests of the child. New York, NY: Free Press;1979.

17) Uniform Marriage and Divorce Act, 9A Uniform Laws Annotated, Sec. 316 (1979).

18) Feller JN, Davidson HA, Hardin M, Horowitz RM. Working with the courts in child protection. Washington, DC: U.S. Department of Health and Human Services; 1992.

19) Shuman DW. The role of mental health experts in custody decisions: science, psychological tests, and clinical judgment. Fam Law Q 2002;36:135-162.

20) Wald M. State intervention on behalf of "neglected" children: a search for realistic standards. Stanford Law Review 1975:27:985-1040.

21) Garrison M. How do judges decide divorce cases?: an empirical analysis of discretionary decision making. North Carol Law Rev 1996;74:401-552.

22) Chambers DL. Rethinking the substantive rules for custody disputes in divorce. Mich Law Rev 1984;83:477-569.

23) Scott ES. Pluralism, paternal preferences, and child custody. Calif Law Rev 1992;80:615-672.

24) Warshak RA. Punching the parenting time clock: the approximation rule, social science, and the baseball bat kids. Fam Court Rev 2007:45:600-619.

25) Mckay J, Shaver-Hast L, Sharnoff W, Warren E, Wright H. A family approach to treatment of postpartum depression. Zero Three 2009; 29:35-39.

26) Jang CG. Child centered judgement in family court. Seoul: Joint Research Committee for Parental Education;2017.

27) Seoul Family Court. Guidance to consultation on familial judgment, familial mediation;2017 [cited 2020 Feb 2]. Available from URL: http://yeslaw.com/lims/front/page/fulltext.html?pAct=view\&pPro mulgationNo $=180178 \#$ nolink.

28) Schwartz LL. A nightmare for King Solomon: the new reproductive technologies. J Fam Psychol 2003;17:229-237.

29) Bernet W. Child custody evaluations. Child Adolesc Psychiatr Clin N Am 2002;11:781-804. 